\title{
Mixing nanoparticles with swine manure to reduce hydrogen sulfide and ammonia emissions
}

\author{
A. C. Alvarado $\cdot$ B. Z. Predicala $\cdot$ D. A. Asis
}

Received: 9 August 2013/Revised: 29 October 2013/Accepted: 2 December 2013/Published online: 8 January 2014

(C) Islamic Azad University (IAU) 2014

\begin{abstract}
Addition of nanoparticles into swine manure was investigated as a possible measure to mitigate the emissions of hydrogen sulfide and ammonia from swine production facilities. Bench-scale experiments were conducted, followed by room-scale tests in controlled environment chambers closely representing actual swine production rooms. Among the 12 types of commercial nanoparticles tested, zinc oxide nanoparticles achieved significant reduction in gaseous hydrogen sulfide and ammonia concentrations when mixed into the manure at a rate of $3 \mathrm{~g}$ zinc oxide nanoparticles per liter of manure slurry. Room-scale experiments showed that mean initial hydrogen sulfide concentrations of 596, 57 and $39 \mathrm{ppm}$ measured at the pit, animal and human levels within each chamber, respectively, were reduced significantly to 5,1 and $1 \mathrm{ppm}$, respectively, after the addition of zinc oxide nanoparticles into the manure. Effectiveness of the treatment was persistent in maintaining low hydrogen sulfide level up to 15 days after treatment application. Pig performance and manure nutrient properties were not adversely affected by the application of zinc oxide nanoparticles.
\end{abstract}

Keywords Environmental emission - Abatement · Zinc oxide $\cdot$ Nanoparticles $\cdot$ Swine

\section{Introduction}

Emissions of ammonia $\left(\mathrm{NH}_{3}\right)$ and hydrogen sulfide $\left(\mathrm{H}_{2} \mathrm{~S}\right)$ from swine facilities pose serious risks to workers and

A. C. Alvarado - B. Z. Predicala $(\bowtie)$. D. A. Asis

Prairie Swine Centre Inc., 2105 8th St E, PO Box 21057,

Saskatoon, SK S7H 5N9, Canada

e-mail: bernardo.predicala@usask.ca animals as well as to the environment. Exposure to specific gases has been documented to cause illnesses or injuries to both animals and humans, and even fatalities at extreme levels of exposure (ASABE 2005; Simensen 1987). Hog farmers were reported to experience inflammatory effects on the respiratory system when exposed to $100 \mathrm{ppm}$ of $\mathrm{NH}_{3}$ and/or $200-300 \mathrm{ppm}$ of $\mathrm{H}_{2} \mathrm{~S}$. In addition, animals exposed continuously to significant gas levels may start to develop pneumonia and respiratory diseases (ASABE 2005). The Occupational Safety and Health Administration (OSHA) has set threshold limits for $\mathrm{NH}_{3}$ at 25 and $35 \mathrm{ppm}$ for an 8-h and 15-min exposure, respectively. Threshold limit values for an 8-h and 15-min exposure to $\mathrm{H}_{2} \mathrm{~S}$, on the other hand, are 10 and $15 \mathrm{ppm}$, respectively (OSHA 2001). Ammonia released to the atmosphere especially from high-density livestock operations may contribute to acid rain (Xue et al. 1998) as well as soil acidification and eutrophication of ground and surface waters through nitrogen enrichment (Casey et al. 2006; Hartung and Phillips 1994).

Ammonia is formed by bacterial and enzymatic breakdown of nitrogen-containing compounds in animal waste while $\mathrm{H}_{2} \mathrm{~S}$ is the product of anaerobic decomposition of sulfur-containing amino acids in the feces (Hartung and Phillips 1994). Because emission of these gases originates largely from animal manure, numerous manure additives were previously investigated for controlling the production of these gases in excreted swine manure and consequently reducing gas emissions. Manure additives included $\mathrm{pH}$ modifiers and acidifiers, digestive additives, oxidizing agents and among other things (McCrory and Hobbs 2001). Acidifiers such as aluminum chloride were effective in reducing $\mathrm{pH}$ and $\mathrm{NH}_{3}$ concentration (Smith et al. 2004); however, 
decreasing the $\mathrm{pH}$ below 7.0 may also favor formation and subsequent emission of $\mathrm{H}_{2} \mathrm{~S}$ (Takeno 2005). Oxidizers such as hydrogen peroxide and potassium permanganate were found effective in oxidizing odorous organic materials into less odorous products (Govere et al. 2005; Williams and Schiffman 1996) thereby reducing $\mathrm{H}_{2} \mathrm{~S}$ emissions, but these oxidizers were also corrosive especially at high concentrations (Shah et al. 2007). Application of digestive additives or mixture of enzymes and microbes into swine manure reduced $\mathrm{NH}_{3}$ and odor levels (Chastain 2000; Schneegurt et al. 2005). However, Williams and Schiffman (1996) found that a digestive deodorant with microorganisms and enzymes was ineffective in treating waste from pig barns. Due to issues with economic viability and inconsistencies in their effectiveness in improving air quality in pig houses (McCrory and Hobbs 2001), most of these treatments are not yet widely adopted in commercial pig farms.

In recent years, advances in nanotechnology have produced nanomaterials such as nanotubes, nanowires and nanoparticles with a scale of $1-100 \mathrm{~nm}$ in at least one dimension (EPA 2007). These nanomaterials were shown to be effective in air purification systems (Kim et al. 2006; Nonami et al. 2004) and groundwater and wastewater treatments (Elliott and Zhang 2001; Hu et al. 2005) due to their unique properties such as higher surface area to volume ratio and higher reactivity compared to regular materials of the same chemical composition. While some applications of nanomaterials such as in environmental remediation have already been investigated comprehensively, the possibilities of applying nanotechnology to address issues with gas emissions from swine facilities have not yet been explored. Thus, this work has been initiated to fill this gap by evaluating the application of commercially available nanoparticles for reducing the levels of $\mathrm{H}_{2} \mathrm{~S}$ and $\mathrm{NH}_{3}$ emissions from swine manure. The objectives of this study were to assess the effectiveness of mixing nanoparticles into swine manure for reducing gaseous emissions under conditions close to an actual production setting and to evaluate the relevant operational factors for effective application of the nanoparticle treatment.

This research was carried out at the barn facility of the Prairie Swine Centre in Saskatoon, Saskatchewan, Canada, from 2007 to 2011.

\section{Materials and methods}

The overall approach of this study was to conduct a comprehensive evaluation of mixing nanoparticles into swine manure to reduce the emissions of $\mathrm{H}_{2} \mathrm{~S}$ and $\mathrm{NH}_{3}$ through a series of experiments at progressively increasing scale. Bench-scale tests were conducted starting from screening tests in closed system setup to select the most promising commercial nanoparticles, followed by semi-pilot scale tests in open system environment to test the selected nanoparticles at various nanoparticle-to-slurry ratios. The most effective treatment combination was then evaluated in room-scale tests which were done in controlled environment chambers simulating actual production conditions to assess the effectiveness of the treatment approach in a farm scale.

Bench-scale tests

A set of 24 different types of commercially available nanoparticles previously used in environmental remediation applications were identified. Out of this set, 12 types of nanoparticles were selected based on a criteria that considered relevant properties (toxicity, flammability, stability and reactivity), similarity of previous applications to potential barn applications and cost of the nanomaterial, for detailed testing in this study. The 12 selected nanoparticles included aluminum oxide $\left(\mathrm{Al}_{2} \mathrm{O}_{3}\right)$, magnesium oxide $(\mathrm{MgO})$, calcium oxide $(\mathrm{CaO})$, aluminum oxide plus $\left(\mathrm{Al}_{2} \mathrm{O}_{3}{ }^{+}\right)$(plus sign being a proprietary label used by a manufacturer to distinguish from corresponding basic nanomaterial of the same chemical composition), magnesium oxide plus $\left(\mathrm{MgO}^{+}\right)$, titanium dioxide $\left(\mathrm{TiO}_{2}\right)$, zinc oxide $(\mathrm{ZnO})$, lanthanum oxide $(\mathrm{LaO})$, manganese oxide $(\mathrm{MnO})$, calcium oxide plus $\left(\mathrm{CaO}^{+}\right)$, iron oxide $\left(\mathrm{Fe}_{3} \mathrm{O}_{4}\right)$ and tungsten oxide $\left(\mathrm{WO}_{3}\right)$.

Manure slurry samples at about 3 weeks old were collected from one manure pit of a grow-finish room at the barn facility of Prairie Swine Centre, Inc. (PSCI), Saskatoon, Saskatchewan, Canada, using a submersible vacuum pump (Model WS-BHS, Goulds Pumps, ITT Corp., NY, USA). To minimize variability in manure composition, the area of the pit where the manure slurry samples were taken was mixed thoroughly prior to manure collection. The collected manure slurry was then placed in an open cylindrical tub and mixed again before finally being transferred to individual containers used in subsequent tests.

\section{Screening tests in closed system}

The effect of mixing nanoparticles with swine manure on $\mathrm{H}_{2} \mathrm{~S}$ and $\mathrm{NH}_{3}$ emissions was investigated in a bench-scale closed system setup in order to have better control over the test conditions. Experiments were conducted in individual 
20-L closed containers filled with $4 \mathrm{~L}$ of manure slurry and stored for 2 days prior to the test. Each of the 12 selected nanoparticles was applied to 3 containers at a nanoparticleto-slurry ratio of $0.1 \mathrm{~g}$ nanoparticles per liter of slurry, which was determined from the study of Elliott and Zhang (2001) and from the initial tests done. The closed container had a lid with two ports connected to a sampling loop: one port was for withdrawing headspace gas to be passed through gas analyzers and the other port to return the gas to the container headspace after passing through the gas analyzers. Gas levels were monitored before treatment application to determine the initial concentration and at 1 day after the nanoparticles were applied. Prior to gas sampling, the manure slurry in the container was agitated manually for $1 \mathrm{~min}$ and then left undisturbed for another minute after agitation. Headspace gas was then extracted using a peristaltic pump (Masterflex L/S pump, Model 7017-52 pump head, Cole-Parmer, Vernon Hills, USA) and passed through the gas analyzers. The top 4 nanoparticles that resulted to the highest reduction in $\mathrm{H}_{2} \mathrm{~S}$ and $\mathrm{NH}_{3}$ (based on the percent change of gas concentration before and after the application of nanoparticles) were re-tested using the same experimental procedure, and the most effective nanoparticle was then selected for subsequent tests.

\section{Semi-pilot scale tests in open system}

The performance of the most effective nanoparticle identified in the previous tests and the nanoparticle-to-slurry ratio required to achieve maximum reduction of $\mathrm{H}_{2} \mathrm{~S}$ and $\mathrm{NH}_{3}$ emissions were evaluated in this experiment. Unlike in the screening tests described above, these semi-pilot scale tests were done in an open system environment to simulate conditions close to an actual swine room. Experiments were conducted in 65-L open top containers (experimental totes) filled with $50 \mathrm{~L}$ of manure; each tote had two 0.4-cm-diameter polyethylene tubing sampling lines installed near its center. The inlet to each sampling line had a plastic funnel which was placed at $5 \mathrm{~cm}$ above the manure surface as suggested by Jacobson et al. (1997) to capture the gases emitted from the manure surface. Initial tests conducted in the open system setup showed that the nanoparticle application rate used in the previous tests ( $0.1 \mathrm{~g}$ nanoparticles per liter of slurry) resulted to only a slight reduction in $\mathrm{H}_{2} \mathrm{~S}$ level. Thus, the nanoparticle-toslurry ratios tested in this experiment were increased to 1.5 , 3, 6 and $8 \mathrm{~g}$ of $\mathrm{ZnO}$ per liter of slurry in an attempt to obtain greater reduction in gas concentration. One container was designated as a Control and did not receive any treatment. Three replicate trials were done; each trial lasted for 20 days.
Manure samples in individual totes were left undisturbed until the first sampling event (Day 5 of the trial). The concentration of gases measured within each container on Day 5 served as baseline data for subsequent sampling events (Days 10, 15 and 20 of the trial). Zinc oxide nanoparticles (treatment) were incorporated into the slurry using a portable mixer immediately after the first gas sampling event on Day 5. Thus, gas sampling done on Days 10, 15 and 20 of each trial corresponded to 5, 10 and 15 days after the treatment has been applied, respectively. During sampling, the manure slurry was mechanically agitated using a mixer. Two representative gas samples were extracted at $2 \mathrm{~min}$ from the start of agitation by means of a gas sampling apparatus that filled 10-L Tedlar bags (SKC Inc., Eighty Four, PA, USA) from sampling lines with inlet placed just above the surface of the manure in each tote. Gas samples in Tedlar bags were analyzed for $\mathrm{H}_{2} \mathrm{~S}$ and $\mathrm{NH}_{3}$ concentrations. In addition, manure $\mathrm{pH}$ was measured in situ using a digital portable $\mathrm{pH}$ meter (Orion 250A, Thermo Scientific, Beverly, MA, USA, accuracy $\pm 0.02)$ after every sampling.

\section{Room-scale tests}

\section{Test rooms and animals}

Using the most effective nanoparticle-to-slurry ratio determined in previous tests, the effectiveness of mixing $\mathrm{ZnO}$ nanoparticles into the slurry for reducing gas emissions was evaluated in room-scale tests closely representing actual barn conditions. The experiment was conducted in two identical controlled environment chambers at PSCI barn facility. One chamber was configured as a normal swine room (Control) with no treatment applied while the manure slurry in the other chamber was treated with $\mathrm{ZnO}$ nanoparticles (Treatment). Each chamber has inside dimensions of $4.2 \mathrm{~m}(L) \times 3.6 \mathrm{~m}(W) \times 2.7 \mathrm{~m}(H)$ with ceiling and internal walls covered with stainless steel sheets to eliminate emissions from these surfaces. Both chambers housed an equal-sized pen with partial slatted concrete flooring within the pen area (Fig. 1). The pen had a commercial feeder and cup-type water drinker, and was surrounded with plastic matrix flooring for easy access to the collection tub underneath the slatted portion of the pen floor. Each collection tub in the two chambers had a capacity of approximately $900 \mathrm{~L}$. Before the start of each experiment, both chambers were cleaned and disinfected thoroughly. The feeders and manure collection tubs were emptied and washed.

The two chambers and the adjacent instrumentation room were located inside one big airspace operated on a negative pressure ventilation system. Fresh air entered into this airspace through ceiling inlets and conditioned at 
Fig. 1 Top view (a) and side view (b) of one of the environmental chambers used in room-scale experiments; the second chamber is identical to this chamber. Not drawn to scale
A

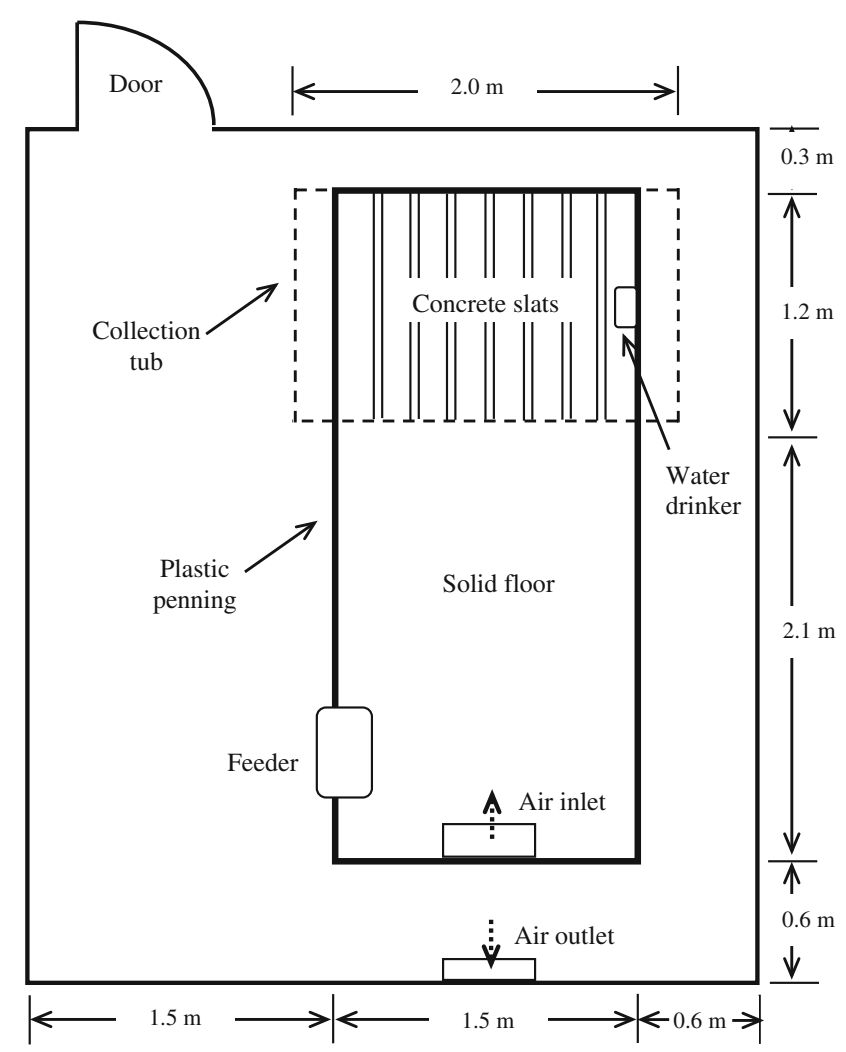

B

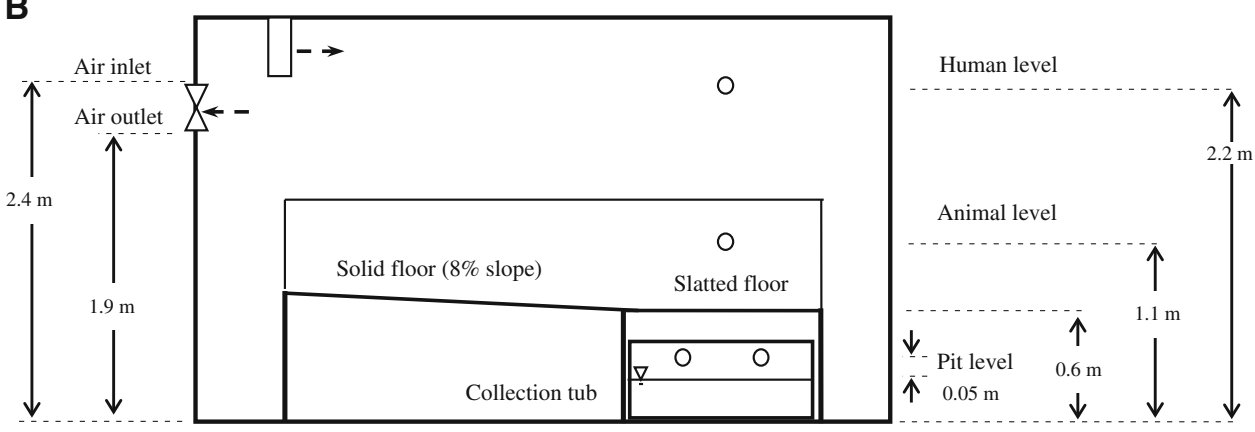

desired settings using a 5-t air-conditioning unit (Raka-060 CAZ, Setra Systems, Boxborough, MA, USA) or a $10-\mathrm{kW}$ electric heater (Chromalox, Dimplex North America Ltd., Cambridge, ON, Canada). The pre-conditioned room air was passed through a filtration unit (Circul-Aire USAH204-B, Dectron International, Roswell, GA, USA) with a 0.6-m-diameter centrifugal fan (Delhi BIDI-20, Delhi Industries Inc., Delhi, ON, Canada) and entered the chambers through an actuated inlet located on the ceiling of each chamber. An additional 2-kW in-duct heater was installed in the supply duct of each chamber to add heat when necessary. Air from each chamber was exhausted through one sidewall fan (H18, Del-Air Systems Inc., Humboldt, SK, Canada). Ventilation rate in each chamber was monitored through an iris damper installed at the exhaust duct of each chamber. The pressure difference across the damper was measured using a pressure transducer (Model 264, Setra Systems, Inc., Boxborough, MA; accuracy of $\pm 6 \mathrm{~Pa}$ ). Except for the air-conditioning unit, all equipment was controlled with a Rapid Control System (Del-Air Systems Inc., Humboldt, SK, Canada). Sensors and other monitoring instruments deployed in each room were calibrated and checked to ensure proper operation during the course of the test.

Eight female grower pigs ranging from 28 to $30 \mathrm{~kg}$ each were housed in each pen within the chamber. The animals were weighed and sorted at the start of each trial such that the average initial weights in both chambers were within 
$\pm 1 \mathrm{~kg}$ of each other. Standard grow-finish diets were provided to the pigs during the course of the trials. In addition, daily checks were done to monitor the health status of the animals.

\section{Experimental procedure}

This test was carried out in three replicate trials, with each trial lasting for 30 days. The first 15 days of the trial served as manure accumulation period. First gas sampling was done on Day 15 of the trial to determine the initial gas concentration in each chamber. Immediately after the first sampling, $\mathrm{ZnO}$ nanoparticles at a rate of $3 \mathrm{~g} / \mathrm{L}$ (determined from semi-pilot scale tests) were applied to the manure slurry in the manure collection tub under the slats in one of the chambers (treated). Treatment application was done by first measuring the volume of manure slurry in the collection tub (based on pre-calibrated depth measurements) and then incorporating the required amount of nanoparticles into a plastic bucket filled with $30 \mathrm{~L}$ of manure taken from the same collection tub. The nanoparticle-manure mixture was then poured back into the tub and mixed with the bulk of the slurry using a steel rake which was gently pulled over the entire length of the tub four times to ensure uniform distribution. Subsequent sampling events were done on Days 20, 25 and 30 which corresponded to 5, 10 and 15 days, respectively, after treatment application.

To monitor the concentrations of $\mathrm{NH}_{3}$ and $\mathrm{H}_{2} \mathrm{~S}$ in the two chambers and to assess their spatial variation within the chamber air space, sampling lines were placed at three specific locations in each chamber (Fig. 1b): at the manure collection tub to represent the manure pit in actual swine production room (approximately $5 \mathrm{~cm}$ above manure surface), at pig's height to represent the animal-occupied zone (approximately $0.5 \mathrm{~m}$ above the pen floor) and at human level to represent the worker-occupied zone (approximately $1.6 \mathrm{~m}$ above the floor). During sampling, manure slurry in the tub was agitated using a steel rake and a recirculating vacuum pump to simulate the handling of the slurry during periodic clearing of manure deposited in underfloor pits in normal swine production rooms. The agitators were operated continuously for $5 \mathrm{~min}$. Air samples were extracted at 2, 5 and $10 \mathrm{~min}$ from the start of agitation through the sampling lines of the gas sampling apparatus used in previous tests and collected in 10-L Tedlar bags. Prior to gas collection, the Tedlar bags and sampling lines were purged with clean air (zero gas) twice. Pigs were moved to an adjacent room during sampling and were returned after the room was sufficiently ventilated.

In addition to measurement of the levels of the target gases, the effects of the treatment on manure production rate, water usage, manure physicochemical characteristics and pig performance such as average daily gain and feed intake were also monitored. Feed supplied to each feeder was weighed to monitor feed intake, and the final weight of the pigs was taken at the end of the trial to determine average daily gain. Manure samples collected at the end of each trial were sent to commercial analytical laboratory for analysis of manure composition and nutrients.

Throughout the test, the management of the two chambers was kept as identical as possible and in accordance with conventional husbandry practices in normal production rooms. Air temperature was initially set at $21^{\circ} \mathrm{C}$ and then gradually decreased to $18{ }^{\circ} \mathrm{C}$ at Week 4 following standard temperature guidelines for grower pigs (PSCI 2000). Air temperature, relative humidity and ventilation rate in each chamber were regularly monitored to ensure that both rooms had the same environmental conditions.

\section{Gas analysis}

Gas samples in Tedlar bags were analyzed for $\mathrm{H}_{2} \mathrm{~S}$ and $\mathrm{NH}_{3}$ concentrations. A $\mathrm{H}_{2} \mathrm{~S}$ monitor with electrochemical sensor (Draeger PAC III, Draeger Canada Ltd., Ontario, Canada; accuracy of $\pm 5 \%$ of reading) was used for monitoring $\mathrm{H}_{2} \mathrm{~S}$ concentration while a $\mathrm{NH}_{3}$ analyzer (Model Chillgard RT, MSA Canada, Edmonton, AB; accuracy of $\pm 2 \mathrm{ppm}$ ) was used to measure $\mathrm{NH}_{3}$ levels. These analyzers were connected in series using Teflon tubing (approximate ID: $0.4 \mathrm{~cm}$ ) so that the same gas sample was analyzed for both gases. Using a peristaltic pump (Masterflex L/S pump, Model 7017-52 pump head, Cole-Parmer, Vernon Hills, USA), gas samples were withdrawn from the bags and introduced to $\mathrm{H}_{2} \mathrm{~S}$ and $\mathrm{NH}_{3}$ analyzers at a rate of 0.5 and $1.1 \mathrm{~L} / \mathrm{min}$, respectively. Flow rate requirement of the analyzers was achieved by installing flow meters with needle valve to adjust flow (Aalborg Flowmeter, Instrument and Controls Inc., NY, USA). Prior to analysis, the gas analyzers were calibrated using standard gases and were programmed to record data every minute. Similarly, $\mathrm{H}_{2} \mathrm{~S}$ readings were recorded in the internal datalogger of the $\mathrm{H}_{2} \mathrm{~S}$ monitoring device while the signal from $\mathrm{NH}_{3}$ analyzer was logged in an external datalogger (CR1000, Campbell Scientific, Logan, UT, USA), both at 1-min intervals.

\section{Results and discussion}

Bench-scale tests

Because of the variability in the initial $\mathrm{H}_{2} \mathrm{~S}$ and $\mathrm{NH}_{3}$ concentrations measured from the different manure samples prior to application of the nanoparticle treatment, 

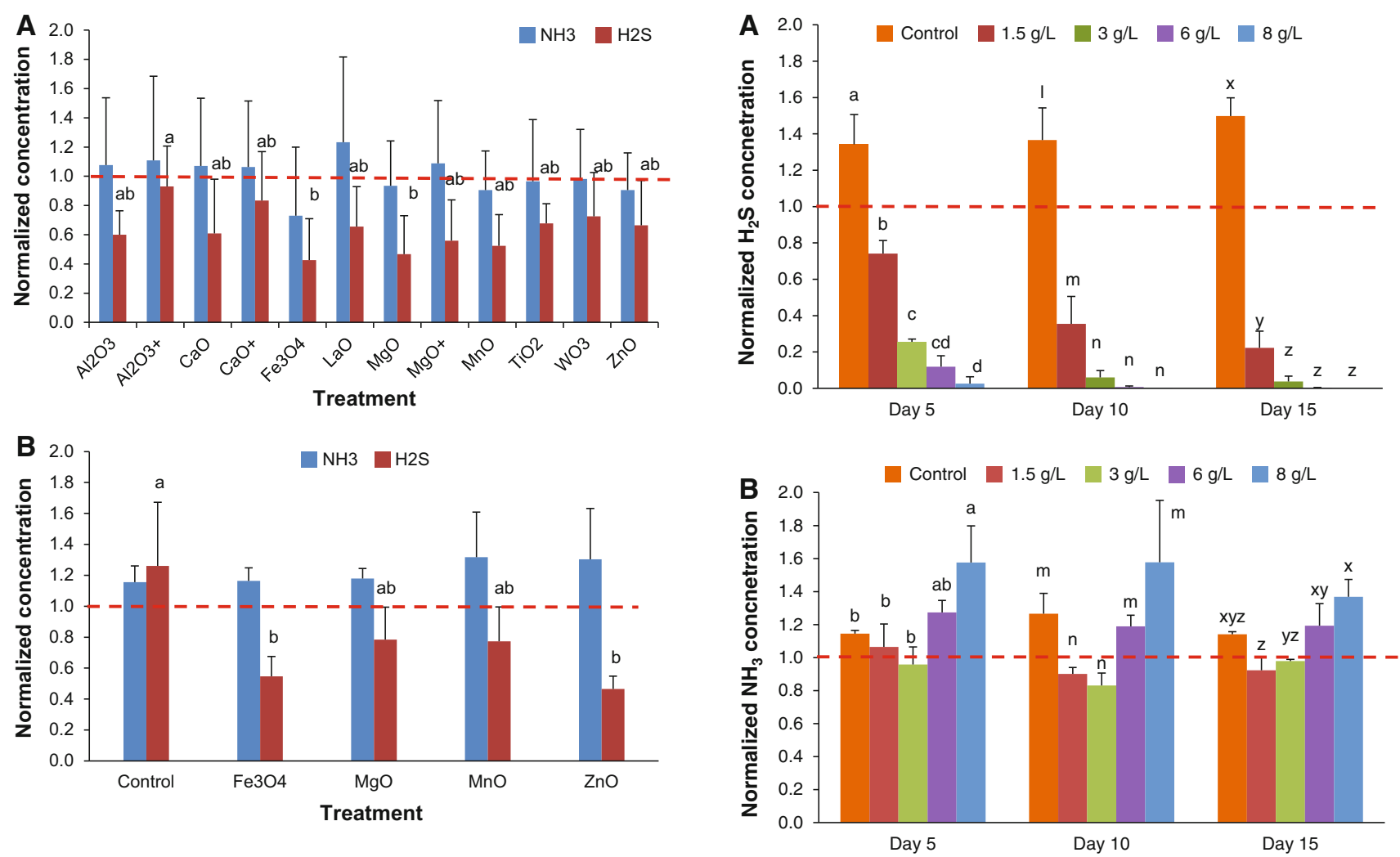

Fig. 2 Mean $( \pm S D)$ normalized concentrations of $\mathrm{H}_{2} \mathrm{~S}$ and $\mathrm{NH}_{3}$ from manure samples treated with 12 types of nanoparticles (a) and from samples treated with the top 4 nanoparticles in verification tests (b), $n=3$. Mean with the same letters for $\mathrm{H}_{2} \mathrm{~S}$ is not significantly different $(P>0.05) . \mathrm{NH}_{3}$ values in each test are not significantly different $(P>0.05)$ from each other

expressing the results in terms of normalized concentrations enabled a reasonable comparison of the impact of the treatments on $\mathrm{H}_{2} \mathrm{~S}$ and $\mathrm{NH}_{3}$ concentrations. Actual concentrations of the target gases were normalized by taking the ratio of the actual final and initial concentrations; as such, normalized concentration values much lower than 1.0 (dashed line in Figs. 2, 3, 4) indicate better effectiveness in reducing the level of the target gas.

\section{Screening tests}

In this test, the effectiveness of the 12 types of nanoparticles in reducing both $\mathrm{H}_{2} \mathrm{~S}$ and $\mathrm{NH}_{3}$ gases was investigated, of which the top four nanoparticles were selected and re-evaluated in verification tests to determine the most effective type of nanoparticles. Normalized gas concentrations from manure samples with the 12 types of nanoparticles added are shown in Fig. 2a. In general, all 12 types of nanoparticles achieved reduction of $\mathrm{H}_{2} \mathrm{~S}$ levels from initial concentrations which ranged from 501 to

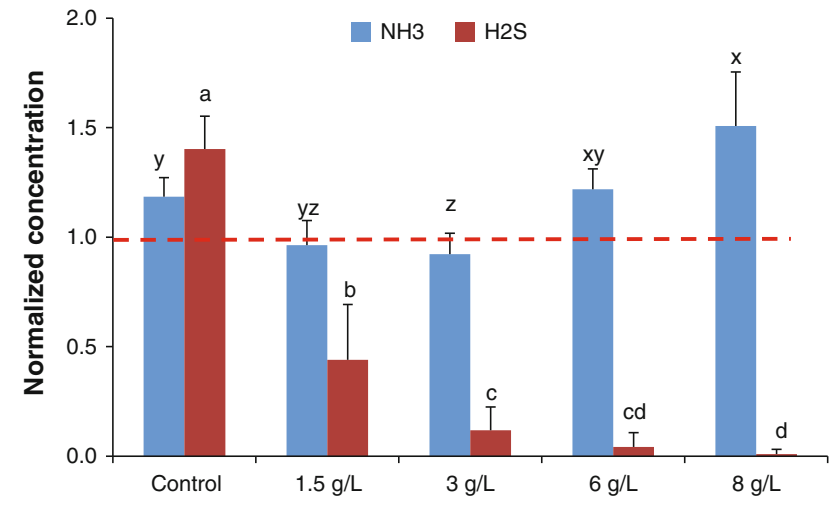

Fig. 4 Effect of $\mathrm{ZnO}$ nanoparticles on $\mathrm{H}_{2} \mathrm{~S}$ and $\mathrm{NH}_{3}$ expressed in normalized concentration during semi-lot scale tests, $n=9$. Mean with the same letters for the same colored bar is not significantly different $(P>0.05)$

1,000 ppm. The addition of $\mathrm{Fe}_{3} \mathrm{O}_{4}$ nanoparticles into the slurry resulted to about $57 \% \mathrm{H}_{2} \mathrm{~S}$ reduction, the highest among all treatments. On the other hand, only six types of nanoparticles were able to reduce $\mathrm{NH}_{3}$ levels. These 
included $\mathrm{Fe}_{3} \mathrm{O}_{4}, \mathrm{ZnO}, \mathrm{MnO}, \mathrm{MgO}, \mathrm{TiO}_{2}$ and $\mathrm{WO}_{3}$ nanoparticles which showed 27, 9, 9, 6, 3 and $2 \% \mathrm{NH}_{3}$ reduction, respectively, from initial levels which ranged from 44 to $103 \mathrm{ppm}$. Zinc oxide, $\mathrm{MnO}, \mathrm{MgO}, \mathrm{TiO}_{2}$ and $\mathrm{WO}_{3}$ nanoparticles had $\mathrm{H}_{2} \mathrm{~S}$ reduction of about $34,48,53$, 32 and $27 \%$, respectively. Thus, the top four most promising nanoparticles were $\mathrm{Fe}_{3} \mathrm{O}_{4}, \mathrm{MgO}, \mathrm{MnO}$ and $\mathrm{ZnO}$, based on their capability to reduce the concentration of both target gases from the manure samples.

These four nanoparticles were selected for verification tests, with results shown in Fig. $2 b$, together with an untreated (control) manure sample for comparison. In contrast to the results from the previous test, $\mathrm{NH}_{3}$ levels from all samples including the control increased at 1 day after treatment application. Increase in $\mathrm{NH}_{3}$ concentration of the treated samples could not be attributed to the addition of nanoparticles into the manure considering that the untreated sample also showed increasing trend. Further, statistical analysis revealed that the increase in $\mathrm{NH}_{3}$ levels from the untreated and treated manure samples relative to their initial values was not significantly different from each other $(P>0.05)$. The effect of the treatment in reducing $\mathrm{H}_{2} \mathrm{~S}$ concentration was more evident than in the previous test. While untreated sample showed about $26 \%$ increase in $\mathrm{H}_{2} \mathrm{~S}$ level, samples with $\mathrm{ZnO}$ and $\mathrm{Fe}_{3} \mathrm{O}_{4}$ nanoparticles added showed significant decrease $(P<0.05)$ from initial levels before treatment application. Zinc oxide nanoparticles achieved the highest $\mathrm{H}_{2} \mathrm{~S}$ reduction (54\%), which was $9 \%$ better but not significantly different $(P>0.05)$ from $\mathrm{Fe}_{3} \mathrm{O}_{4}$ nanoparticles. Considering that $\mathrm{ZnO}$ nanoparticles were about sevenfold cheaper than $\mathrm{Fe}_{3} \mathrm{O}_{4}$ nanoparticles, the economics of treatment application combined with its observed effectiveness in reducing the target gases resulted in the selection of $\mathrm{ZnO}$ nanoparticles as the most effective type of nanoparticles among the four treatments, and was subsequently used in further tests.

\section{Semi-pilot scale tests}

Figure 3a presents the normalized concentration of $\mathrm{H}_{2} \mathrm{~S}$ from untreated manure and those treated with varying amounts of $\mathrm{ZnO}$ nanoparticles; the average initial $\mathrm{H}_{2} \mathrm{~S}$ concentrations ranged from 460 to $710 \mathrm{ppm}_{2} \mathrm{~S}$. While the $\mathrm{H}_{2} \mathrm{~S}$ levels in untreated manure samples increased over the trial period, the concentration of $\mathrm{H}_{2} \mathrm{~S}$ in the treated slurry decreased substantially as the trial progressed. Significant reduction $(P<0.05)$ in $\mathrm{H}_{2} \mathrm{~S}$ levels was observed in treated manure samples starting from Day 5 after the treatment has been applied. On Day 15 after $\mathrm{ZnO}$ application, $\mathrm{H}_{2} \mathrm{~S}$ concentrations of the samples treated with 3,6 and $8 \mathrm{~g} / \mathrm{L}$ of $\mathrm{ZnO}$ achieved more than $95 \%$ reduction in $\mathrm{H}_{2} \mathrm{~S}$ levels (relative to Day 0 values) while the $1.5 \mathrm{~g} / \mathrm{L}$ treatment and the control showed $78 \%$ reduction and $50 \%$ increase, respectively. The observed decrease in $\mathrm{H}_{2} \mathrm{~S}$ levels could be attributed to the addition of $\mathrm{ZnO}$ nanoparticles since the control (untreated) systems showed increasing $\mathrm{H}_{2} \mathrm{~S}$ trends during the 15-day monitoring period. Furthermore, these results also demonstrated the persistence of the treatment effect because appreciable $\mathrm{H}_{2} \mathrm{~S}$ reduction was observed up to 15 days after $\mathrm{ZnO}$ incorporation into the slurry.

On average, $\mathrm{NH}_{3}$ concentration from all manure samples regardless of contact time ranged from 19 to $30 \mathrm{ppm}$. Examination of the change in actual $\mathrm{NH}_{3}$ levels with respect to its initial value through normalization procedures as shown in Fig. 3b revealed significant differences among treatments including the control and was significantly $(P<0.05)$ influenced by the amount of nanoparticles applied. The addition of 6 and $8 \mathrm{~g} / \mathrm{L}$ of $\mathrm{ZnO}$ nanoparticles to the slurry as well as the untreated manure samples exhibited an increase in $\mathrm{NH}_{3}$ levels over the monitoring period, while the opposite was observed for 1.5 and $3 \mathrm{~g} / \mathrm{L}$ treatments. The increase in $\mathrm{NH}_{3}$ levels for 6 and $8 \mathrm{~g} / \mathrm{L}$ treatments could possibly be due to excessive application of $\mathrm{ZnO}$ nanoparticles into the manure. In the $\mathrm{H}_{2} \mathrm{~S}$ desulfurization experiment of Wang et al. (2008), $\mathrm{ZnO}$ at higher rates blocked the active centers for desulfurization causing unfavorable chemistry such as increase in $\mathrm{pH}$. The increase in $\mathrm{pH}$ in swine manure, which was observed in $6 \mathrm{~g} / \mathrm{L}$ (7.4-8.8) and $8 \mathrm{~g} / \mathrm{L}$ (7.4-8.9) treatments, can lead to higher conversion rates of ammonium ion to $\mathrm{NH}_{3}$ gas, thus resulting to increase in ammonia volatilization (Hartung and Phillips 1994). Comparison of means among all treatments including the control showed that manure sample with $3 \mathrm{~g} / \mathrm{L}$ of $\mathrm{ZnO}$ nanoparticles applied was significantly different $(P<0.05)$ from 6 and $8 \mathrm{~g} / \mathrm{L}$ treatments as well as the control but not significantly different from the $1.5 \mathrm{~g} / \mathrm{L}$ treatment $(P>0.05)$. Over the 15 -day period, the maximum $\mathrm{NH}_{3}$ reduction was only about $8 \%$ which was obtained from the samples with $3 \mathrm{~g} / \mathrm{L}$ of $\mathrm{ZnO}$ nanoparticles added, indicating that the treatment caused minimal effect on $\mathrm{NH}_{3}$ concentrations.

In order to evaluate the comparative effect of the treatment on $\mathrm{H}_{2} \mathrm{~S}$ and $\mathrm{NH}_{3}$, and consequently to determine the nanoparticle-to-slurry ratio that worked effectively for both gases, normalized concentrations of $\mathrm{H}_{2} \mathrm{~S}$ and $\mathrm{NH}_{3}$, averaged over 15 days, at various application rate levels were plotted against each other in Fig. 4. It can be observed that as the nanoparticle-to-slurry ratio increased, the effectiveness of the treatment to reduce $\mathrm{H}_{2} \mathrm{~S}$ also increased. However, the treatment was found to be less effective in reducing $\mathrm{NH}_{3}$ levels. Among all treatments, $3 \mathrm{~g} / \mathrm{L}$ achieved the highest 

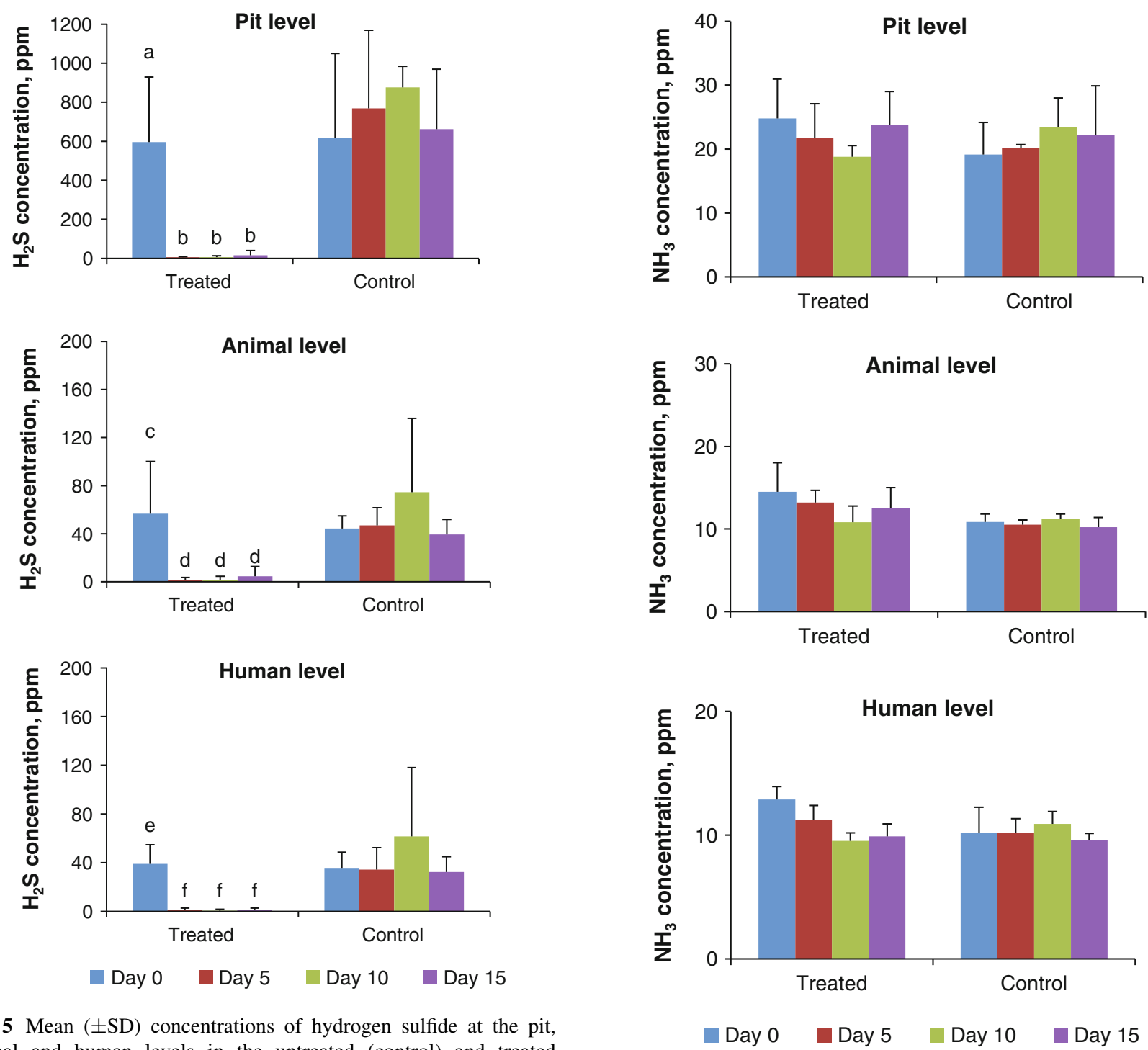

5 Mean $( \pm S D)$ concentrations of hydrogen sulfide at the pit, animal and human levels in the untreated (control) and treated chambers during room-scale tests, $n=3$. Mean with the same letters within the same sampling location in the treated chamber is not significantly different $(P>0.05) . \mathrm{H}_{2} \mathrm{~S}$ levels at the pit, animal and human zones in the control chamber were not significantly different $(P>0.05)$ from each other over the 15 -day monitoring period

$\mathrm{NH}_{3}$ reduction. From these observations, it was apparent that treatment with $3 \mathrm{~g} \mathrm{ZnO}$ nanoparticles per liter of slurry could reduce the concentrations of both $\mathrm{H}_{2} \mathrm{~S}$ and $\mathrm{NH}_{3}$, thus this application rate was used in the room-scale tests.

Room-scale tests

\section{Effect on $\mathrm{H}_{2} \mathrm{~S}$ concentrations}

Figure 5 shows the actual $\mathrm{H}_{2} \mathrm{~S}$ concentrations measured at 2 min from the start of agitation in the control and treated

chambers; these represent critical levels which could cause exposure concerns in actual pig production rooms compared to the gas levels measured at 5 and $10 \mathrm{~min}$ after the start of agitation. To account for the non-homogenous nature of manure (Ndegwa and Zhu 2003) and the inherent variation in the initial concentration of manure gases, gas samples were collected at different locations in each chamber prior to treatment application (in the treated chamber). The $\mathrm{H}_{2} \mathrm{~S}$ concentrations on this day were plotted as Day 0 values, which served as baseline for comparing corresponding values from subsequent sampling events. 
Table 1 Performance of pigs and characteristics of manure samples collected from each chamber during room-scale tests (mean \pm SD, $n=3)$

\begin{tabular}{|c|c|c|}
\hline Parameters & Treated & Control \\
\hline \multicolumn{3}{|l|}{ Pig performance } \\
\hline Average daily water usage (L/day-pig) & $2.2 \pm 0.8$ & $2.4 \pm 0.1$ \\
\hline Average daily manure production (L/day-pig) & $2.28 \pm 0.24$ & $2.33 \pm 0.15$ \\
\hline Average daily feed intake, ADFI (kg/day-pig) & $1.70 \pm 0.19$ & $1.74 \pm 0.14$ \\
\hline Average daily gain, ADG (kg/day-pig) & $0.79 \pm 0.03$ & $0.82 \pm 0.05$ \\
\hline \multicolumn{3}{|l|}{ Manure characteristics } \\
\hline Moisture (\%) & $86.40 \pm 3.58$ & $89.00 \pm 4.56$ \\
\hline Total solids $(\%)$ & $13.60 \pm 3.58$ & $10.99 \pm 4.57$ \\
\hline Conductivity, EC ( $\mu \mathrm{S} / \mathrm{cm})$ & $17,020 \pm 9,960$ & $24,330 \pm 1,460$ \\
\hline $\mathrm{pH}$ & $7.27 \pm 0.21$ & $7.09 \pm 0.04$ \\
\hline Total Kjeldahl nitrogen $(\mathrm{mg} / \mathrm{kg})$ & $9,400 \pm 2,200$ & $8,400 \pm 1,700$ \\
\hline Ammonium-N (mg/kg) & $5,700 \pm 1,400$ & $5,500 \pm 1,100$ \\
\hline Calcium, Ca (mg/kg) & $2,400 \pm 1,200$ & $1,700 \pm 700$ \\
\hline Copper, $\mathrm{Cu}(\mathrm{mg} / \mathrm{kg})$ & $50 \pm 28$ & $38 \pm 15$ \\
\hline Iron, $\mathrm{Fe}(\mathrm{mg} / \mathrm{kg})$ & $294 \pm 131$ & $223 \pm 127$ \\
\hline Magnesium, Mg (mg/kg) & $1,600 \pm 500$ & $1,200 \pm 400$ \\
\hline Manganese, Mn (mg/kg) & $90 \pm 32$ & $69 \pm 24$ \\
\hline Phosphorus, P (mg/kg) & $3,000 \pm 1,200$ & $2,300 \pm 900$ \\
\hline Potassium, K (mg/kg) & $4,800 \pm 1,100$ & $4,300 \pm 900$ \\
\hline Sodium, Na (mg/kg) & $1,400 \pm 300$ & $1,300 \pm 200$ \\
\hline Sulfur, S (mg/kg) & $1,600 \pm 400$ & $1,300 \pm 100$ \\
\hline Zinc, $\mathrm{Zn}(\mathrm{mg} / \mathrm{kg})^{\mathrm{a}}$ & $1,848 \pm 708$ & $194 \pm 82$ \\
\hline
\end{tabular}

${ }^{a}$ Amount of zinc in treated and untreated manure samples was significantly different $(P<0.05)$

In the treated chamber, initial $\mathrm{H}_{2} \mathrm{~S}$ concentrations of 596, 57 and $39 \mathrm{ppm}$ at the pit, animal and human levels, respectively, were reduced significantly $(P<0.05)$ to 5,1 and $1 \mathrm{ppm}$, respectively, on Day 5 after $\mathrm{ZnO}$ nanoparticles were applied into the manure (Fig. 5). These levels were almost unchanged to Day 15 which implied that the effect of the treatment in reducing $\mathrm{H}_{2} \mathrm{~S}$ levels was persistent up to 15 days or possibly more. On the other hand, levels of $\mathrm{H}_{2} \mathrm{~S}$ at the various sampling locations in the untreated (control) chamber showed increasing trend initially and then decreased after Day 10. It was observed that the amount of manure produced in the control chamber increased sharply from 2.0 and $2.05 \mathrm{~L} /$ pig-day on Days 5 and 10, respectively, to 3.2 L/day-pig on Day 15. This rapid increase in manure production rate could alter the composition and properties of manure deposited in the tub and thus possibly responsible for $\mathrm{H}_{2} \mathrm{~S}$ decrease after Day 10. However, this fluctuation in $\mathrm{H}_{2} \mathrm{~S}$ concentrations at the different sampling locations (pit, animal and human levels) in the untreated (control) chamber was not significantly different $(P>0.05)$ over the 15-day monitoring period. On average, $\mathrm{H}_{2} \mathrm{~S}$ concentrations in the control chamber ranged from 617 to 877,39 to 75 and 32 to $62 \mathrm{ppm}$ at the pit, animal and human levels, respectively.

\section{Effect on $\mathrm{NH}_{3}$ concentrations}

Actual $\mathrm{NH}_{3}$ concentrations measured at all locations within each chamber at $2 \mathrm{~min}$ after start of agitation are plotted in Fig. 6. In the treated chamber, a slight decrease in the $\mathrm{NH}_{3}$ levels at the different sampling locations (pit, animal and human levels) was observed after the addition of $\mathrm{ZnO}$ nanoparticles into the manure slurry. On Day 0 , mean $\mathrm{NH}_{3}$ concentrations at the pit, animal and human zones were 25 , 15 and $13 \mathrm{ppm}$, respectively, which decreased to 19,11 and $10 \mathrm{ppm}$ on Day 10 after treatment application. Ammonia concentrations in all sampling locations measured subsequently after the nanoparticle treatment was applied were not significantly different $(P>0.05)$ from their initial (Day 0) values. In the control chamber, $\mathrm{NH}_{3}$ levels were also unchanged during the 15-day monitoring period. On average, $\mathrm{NH}_{3}$ concentrations at the pit, animal and human levels ranged from 19 to 33,10 to 11 and 10 to $11 \mathrm{ppm}$, respectively. 


\section{Effect on pig performance and manure characteristics}

As shown in Table 1 , no significant difference $(P>0.05)$ in the average daily water usage, manure production rate, average daily feed intake (ADFI) and average daily gain (ADG) of the pigs in the two chambers were observed. Addition of $\mathrm{ZnO}$ nanoparticles into the manure slurry also showed no considerable impact on physical and chemical properties of manure except for a significant increase in the amount of zinc by $1,654 \mathrm{mg} / \mathrm{kg}(P<0.05)$, which was expected because of the treatment applied. In spite of the increase, the zinc content of the treated slurry was below the toxicity limit $(2,800 \mathrm{mg} \mathrm{Zn} / \mathrm{kg})$ set by the US Environmental Protection Agency (EPA 1994) for biosolid applications. However, it is important to note that elevated levels of zinc in the soil could pose potential risks to the soil microbial communities and plants (Broadley et al. 2007; Moffett et al. 2003; Davies 1993; Neuhauser et al. 1985); thus, a full evaluation of the land application of the zinc oxide-treated manure should be conducted.

\section{Discussion}

The reduction of $\mathrm{H}_{2} \mathrm{~S}$ levels after the application of $\mathrm{ZnO}$ nanoparticles into swine manure, as evident in Figs. 4 and 5 , could be attributed to the antibacterial activity of $\mathrm{ZnO}$ nanoparticles and the known capacity of $\mathrm{ZnO}$ for $\mathrm{H}_{2} \mathrm{~S}$ desulfurization.

The antibacterial effect of $\mathrm{ZnO}$ involved two possible mechanisms: (1) distortion of the bacterial cell membrane as a result of the deposition of $\mathrm{ZnO}$ nanoparticles on the surface of bacteria (Brayner et al. 2006; Liu et al. 2009; Zhang et al. 2007) and (2) production of highly reactive oxygen species (ROS) such as peroxide and oxygen ions (Fang et al. 2006; Sawai 2003; Wang et al. 2007; Zhang et al. 2007). Reactive oxygen species, as a product of incomplete oxygen reduction, are toxic to anaerobic microorganisms such as sulfate-reducing bacteria (SRB) (Brioukhanov et al. 2010) which are mainly responsible for the production of $\mathrm{H}_{2} \mathrm{~S}$ in swine manure.

Another factor that could contribute to $\mathrm{H}_{2} \mathrm{~S}$ reduction is the desulfurization of $\mathrm{H}_{2} \mathrm{~S}$ by $\mathrm{ZnO}$. Zinc oxide has been used for removal of $\mathrm{H}_{2} \mathrm{~S}$ in drilling fluids (Davidson 2004; Sayyadnejad et al. 2008) and different gaseous media (Bagreev et al. 2001; Wang et al. 2008) during which the process produced water $\left(\mathrm{H}_{2} \mathrm{O}\right)$ and an insoluble zinc sulfide $(\mathrm{ZnS})$ as shown in the reaction below (Eq. 1):

$\mathrm{ZnO}+\mathrm{H}_{2} \mathrm{~S} \rightarrow \mathrm{ZnS}+\mathrm{H}_{2} \mathrm{O}$.

With the two modes of action exhibited by $\mathrm{ZnO}$ nanoparticles toward $\mathrm{H}_{2} \mathrm{~S}$ mentioned above, a complete mass balance of the chemical reaction shown in Eq. 1 would be helpful in assessing which of these two (i.e., antibacterial activity or desulfurization capacity) had the dominant effect on the reduction of $\mathrm{H}_{2} \mathrm{~S}$. This analysis would require the mass of the reactants $\left(\mathrm{ZnO}\right.$ and $\mathrm{H}_{2} \mathrm{~S}$ ) which was known during the tests, and the mass of $\mathrm{ZnS}$ and $\mathrm{H}_{2} \mathrm{O}$ produced from the reaction; the latter values were not quantified in this present work due to constraints in equipment availability, and thus, further investigation in this area is needed to determine and optimize the factors responsible for the observed reduction in $\mathrm{H}_{2} \mathrm{~S}$ levels.

Unlike $\mathrm{H}_{2} \mathrm{~S}$, only slight reduction in $\mathrm{NH}_{3}$ concentration was achieved from manure samples mixed with $\mathrm{ZnO}$ nanoparticles as shown in Figs. 4 and 6. This could possibly be due to competition between $\mathrm{H}_{2} \mathrm{~S}$ and $\mathrm{NH}_{3}$ molecules for the adsorption sites on $\mathrm{ZnO}$ molecules. In a study conducted by Chung et al. (2005) on biological activated carbon biotrickling filter, the $\mathrm{NH}_{3}$ adsorption period was shortened due to $\mathrm{H}_{2} \mathrm{~S}$ coexistence.

As shown in Figs. 5 and 6, levels of $\mathrm{H}_{2} \mathrm{~S}$ and $\mathrm{NH}_{3}$ at the pit in the chamber during the room-scale experiments were significantly higher $(P<0.05)$ than those observed at the animal and human levels. This observation, which was more evident in the control chamber, was likely due to the minimal air exchange in the underfloor pit area and the dilution of the emitted gases with ventilation air at the animal and human levels.

\section{Conclusion}

Among the 12 types of nanoparticles tested, bench-scale tests showed that mixing $\mathrm{ZnO}$ nanoparticles into the manure had the greatest potential in controlling $\mathrm{H}_{2} \mathrm{~S}$ and $\mathrm{NH}_{3}$ emissions; its effectiveness was significantly influenced by the amount of nanoparticles applied into the manure. Room-scale experiments indicated that the addition of $\mathrm{ZnO}$ nanoparticles into the slurry reduced gas levels, specifically $\mathrm{H}_{2} \mathrm{~S}$, at the source (manure pit), resulting to almost undetectable levels at the animal- and humanoccupied zones. The application of $\mathrm{ZnO}$ nanoparticles had no significant impact on pig performance and manure characteristics.

Acknowledgments The authors would like to acknowledge the Saskatchewan Agriculture Development Fund (2006-0134) and the National Science and Engineering Research Council of Canada (312387-05) for the financial support to this research. Strategic funding provided by Saskatchewan Ministry of Agriculture, Saskatchewan Pork Development Board, Alberta Pork and Manitoba Pork Council to the research programs at Prairie Swine Centre, Inc. (PSCI) was gratefully acknowledged. Technical assistance provided by PSCI barn staff is greatly appreciated. 


\section{References}

ASABE (2005) EP470: manure storage safety. American Society of Agricultural and Biological Engineers, St. Joseph, MI

Bagreev A, Bashkova S, Locke DC, Bandosz TJ (2001) Sewage sludge-derived materials as efficient adsorbents for removal of hydrogen sulphide. Environ Sci Technol 35:1537-1543

Brayner R, Ferrari-Iliou R, Brivois N, Djediat S, Benedetti MF, Fievet F (2006) Toxicological impact studies based on Escherichia coli bacteria in ultrafine $\mathrm{ZnO}$ nanoparticles colloidal medium. Nano Lett 6:866-870

Brioukhanov A, Pieulle L, Dolla A (2010) Antioxidative defense systems of anaerobic sulfate-reducing microorganisms. In: Mendez-Vilas A (ed) Current research, technology and education topics in applied microbiology and microbial biotechnology. Formatex Research Center, Spain, pp 148-159

Broadley MR, White PJ, Hammond JP, Zelko I, Lux A (2007) Zinc in plants. New Phytol 173:677-702

Casey KD, Bicudo JR, Schmidt DR, Signh A, Gay SW, Gates RS, Jacobson LD, Hoff, SJ (2006) Air quality and emissions from livestock and poultry production/waste management systems. In: Rice JM, Caldwell DF, Humenik FJ (eds) Animal agriculture and the environment. National Center for Manure and Animal Waste Management White Papers, ASABE, St. Joseph, MI, pp $1-40$

Chastain JP (2000) Evaluation of biosafe as an additive to reduce odor from swine manure. Clemson University, Clemson, SC. http:// www.clemson.edu/agbioeng/bio/Chastain/Evaluation $\% 20$ of $\%$ 20Biosafe.pdf. Accessed 26 July 2010

Chung Y, Lin Y, Tseng C (2005) Removal of high concentration of $\mathrm{NH}_{3}$ and coexistent $\mathrm{H}_{2} \mathrm{~S}$ by biological activated carbon (BAC) biotrickling filter. Bioresour Technol 96:1812-1820

Davidson E (2004) Method and composition for scavenging sulphide in drilling fluids. US Patent 6476611

Davies BE (1993) Radish as an indicator plant for derelict landuptake of zinc at toxic concentrations. Commun Soil Sci Plant Anal 24:1883-1895

Elliott DW, Zhang WX (2001) Field assessment of nanoscale bimetallic particles for groundwater treatment. Environ Sci Technol 35:4922-4926

EPA (1994) A plain english guide to the EPA part 503. Biosolids Rule, US Environmental Protection Agency. http://www.epa. gov/owm $/ \mathrm{mtb} /$ biosolids $/ 503 \mathrm{pe} /$. Accessed 20 Oct 2010

EPA (2007) Nanotechnology white paper, science policy council. US Environmental Protection Agency, Washington, DC, EPA 100/B-07/001. http://es.epa.gov/ncer/nano/publications/ whitepaper12022005.pdf. Accessed 22 Feb 2010

Fang M, Chen JH, Xu XL, Yang PH, Hildebrand HF (2006) Antibacterial activities of inorganic agents on six bacteria associated with oral infections by two susceptibility tests. Int J Antimicrob Agents 27:513-517

Govere EM, Tonegawa M, Bruns MA, Wheeler EF, Heineman PH, Kephart KB, Dec J (2005) Deodorization of swine manure using minced horseradish roots and peroxides. Agric Food Chem 53:4880-4889

Hartung J, Phillips VR (1994) Control of gaseous emissions from livestock buildings and manure stores. J Agric Eng Res 57:173-189

Hu J, Chen G, Lo IMC (2005) Removal and recovery of Cr(VI) from wastewater by maghemite nanoparticles. Water Res 39:4528-4536

Jacobson L, Radman C, Schimdt D, Nicolai R (1997) Odor measurements from manure storages on Minnesota pig farms.
In: Botthcher RW, Hoff SJ (eds) Proceedings of the fifth international symposium on livestock environment. ASAE, St. Joseph, MI, pp 93-100

Kim JH, Seo G, Cho DL, Choi BC, Kim JB, Park HJ, Kim MW, Song SJ, Kim GJ, Kato S (2006) Development of air purification device through application of thin-film photocatalyst. Catal Today 111:271-274

Liu Y, He L, Mustapha A, Li H, Hu ZQ, Lin M (2009) Antibacterial activities of zinc oxide nanoparticles against Escherichia coli 0157:17. J Appl Microbiol 107:1193-1201

McCrory DF, Hobbs PJ (2001) Additives to reduce ammonia and odor emissions from livestock wastes: a review. J Environ Qual 30:345-355

Moffett BF, Nicholson FA, Uwakwe NC, Chambers BJ, Harris JA, Hill TC (2003) Zinc contamination decreases the bacterial diversity of agricultural soil. FEMS Microbiol Ecol 43:13-19

Ndegwa PM, Zhu J (2003) Novel procedures for accurate sampling of swine manures. In: Proceedings of the 9th international animal, agricultural and food processing wastes. ASABE, St. Joseph, MI, pp 221-229

Neuhauser EF, Loehr RC, Milligan DL, Malecki MR (1985) Toxicity of metals to the earthworm Eisenia fetida. Biol Fertil Soils $1: 149-152$

Nonami T, Hase H, Funakoshi K (2004) Apatite-coated titanium dioxide photocatalyst for air purification. Catal Today 96:113-118

OSHA (Occupational Safety and Health Administration) (2001) OSHA chemical sampling information. http://www.osha.gov/dts/ chemicalsampling/data/CH_246800.html. Accessed 18 Mar 2011

PSCI (2000) Pork production reference guide, 1st edn. Prairie Swine Centre, Saskatoon

Sawai J (2003) Quantitative evaluation of antibacterial activities of metallic oxide powders $(\mathrm{ZnO}, \mathrm{MgO}$ and $\mathrm{CaO})$ by conductimetric assay. J Microbiol Methods 54:177-182

Sayyadnejad MA, Ghaffarian H, Saeidi M (2008) Removal of hydrogen sulphide by zinc oxide nanoparticles in drilling fluid. Int J Environ Sci Tech 5:565-569

Schneegurt MA, Weber DL, Ewing S, Schur H B (2005) Evaluating biostimulant effects in swine production facility wastewater. In: Proceedings of the state of the science of animal manure and waste management symposium. North Carolina State University College of Agriculture and Life Sciences, pp 1-6

Shah S, Westerman P, Grabow G (2007) Additives for improving hog farm air quality. NC State University, Raleigh

Simensen E (1987) Manure gases and manure gas poisonings in livestock. Vet Hum Toxicol 29:61-62

Smith DR, Moore PA Jr, Haggard BE, Maxwell CV, Daniel TC, VanDevander K, Davis ME (2004) Effect of aluminum chloride and dietary phytase on relative ammonia losses from swine manure. J Anim Sci 82:605-611

Takeno N (2005) Atlas of Eh-pH diagrams. Geological survey of Japan open file report No. 419. National Institute of Advanced Industrial Science and Technology, Ibaraki

Wang X, Yang F, Yang W, Yang X (2007) A study on the antibacterial activity of one-dimensional $\mathrm{ZnO}$ nanowire arrays: effects on the orientation and plane surface. Chem Commun 42:4419-4421

Wang X, Sun T, Yang J, Zhao L, Jia J (2008) Low-temperature $\mathrm{H}_{2} \mathrm{~S}$ removal from gas streams with SBA-15 supported $\mathrm{ZnO}$ nanoparticles. Chem Eng J 142:48-55

Williams CM, Schiffman SS (1996) Effect of liquid swine manure additives on odor parameters. In: Proceedings of the interna- 
tional conference on air pollution from agricultural operations. MidWest Plan Service, Kansas City, pp 409-412

Xue S, Chen KS, Hermanson RE (1998) Measuring ammonia and hydrogen sulfide emitted from manure storage facilities. Trans ASABE 41:1125-1130
Zhang LL, Jiang YH, Ding YL, Povey M, York D (2007) Investigation into the antibacterial behaviour of suspensions of $\mathrm{ZnO}$ nanoparticles (ZnO nanofluids). J Nanopart Res 9:479-489 